\title{
The Rule of Compulsory Prosecution and the Scope of Prosecutorial Discretion in Germany*
}

\author{
Joachim Herrmann†
}

Professor Kenneth Gulp Davis has remarked that Americans may have considerable difficulty imagining a criminal justice system based on the concept that the prosecuting authority should have limited, rather than pervasive and uncontrolled, discretionary powers. ${ }^{1}$ A system of this kind does, however, exist. Prosecuting attorneys in West Germany are required, except in certain situations specified in the codes and statutes, to prosecute all charges for which there is sufficient evidence to justify a conviction. ${ }^{2}$ The German prosecutor is not without discretion; the scope of his discretion has increased steadily and is still growing. Unlike the American situation, however, the discretion of the prosecutor in this system is strictly limited by the Code of Criminal Procedure; it is guided by statutory standards and, to a certain extent, is controlled by the courts.

The striking difference between the two systems reasonably causes

- This paper is part of a forthcoming symposium compiled by Professor Kenneth Culp Davis on European experiences with discretionary justice. The author wishes to express his appreciation for encouragement, support, and suggestions given by Professor Davis. The examples of the actual exercise of discretion contained in this paper are based on interviews with prosecutors, defense attorneys, and judges in Freiburg, Munich, and Augsburg. Without their cooperation the research for this paper would not have been possible.

$\dagger$ Visiting Professor of Law, University of Chicago; Professor of Law, University of Augsburg, Germany.

1 K. Davis, Discretionary Justice: A Preliminary Inquiry 191-92 (1971).

2 The duty is stated in $\$ 152(2)$ of the West German Code of Criminal Procedure:

Except as otherwise provided by law, it [i.e., the prosecution] is obligated to take action in case of all acts which are punishable by a court and capable of prosecution, so far as there is a sufficient factual basis.

An English translation of the Code is published in 10 American Series of Foreign Penal Codes: The German Code of Criminal Procedure (H. Niebler transl. 1965) [hereinafter cited as 10 Foreign Penal Codes].

The German prosecutorial system recently has come under much discussion. See K. Davis, supra note 1, at 193-95; Jescheck, The Discretionary Powers of the Prosecuting Attorney in West Germany, 18 AM. J. CoMP. L. 508 (1970); Schmidt, Introduction to CoDE of Crtminal Procedure, 10 Foreign Penal Codes, supra, at 10; Schram, The Obligation to Prosecute in West Germany, 17 AM. J. CoMP. L. 627 (1969). See also Foreign OfFICE, 2 Manuad of German Law 140 (1952); Williams, Discretion in Prosecuting, 1956 CrIm. L. REv. 222; Wolff, Criminal Justice in Germany (pt. 1), 42 Mrcr. L. REv, 1067, 1077-78 (1944). 
Americans to wonder how the German prosecutor manages to do his job, despite this restricted discretion, in a way that seems to be accepted by the public. There is no quick and simple answer; various social, political, and legal factors have to be taken into consideration. If an inquiry were initially directed to the question of how prosecuting attorneys make practical use of their discretionary powers, we could gain only limited insights into the working of the German system. It is more helpful to begin by explaining the origin of the idea of compulsory prosecution in the German system and why it is today considered the fundamental principle governing the prosecutor's activities. This article will also briefly show, by examining the German Penal Code, that problems solved by the wide discretion of the American prosecutor do not exist, or are solved by other means, in Germany. Only then can the discussion meaningfully turn to its main focus, an investigation of the extent of the prosecutor's discretion, its limits, and its pattern, both in theory and in practice.

\section{The Development of the Concept of Compulsory Prosecution}

The office of the prosecutor was created in the German states in the middle of the nineteenth century by splitting the investigative and judicial functions of the inquisitorial judge. The investigative function was entrusted to a separate official, the prosecutor. ${ }^{3}$ Some states, particularly in the south, decided that the prosecutor should be legally bound to prosecute a charge whenever there was sufficient evidence to obtain a conviction; other states, including Prussia, gave broad discretionary powers to the prosecutor.4 The Code of Criminal Procedure of the German Reich was enacted in 1877 and, with numerous revisions, is still in effect in Germany. The Code adopted the idea of compulsory prosecution; equal enforcement of the criminal law and protection against prosecutorial arbitrariness were deemed predominant values.

Although the power to prosecute crimes in Germany was separated from the inquisitorial judge, it continued to be entrusted to the judicial branch, under the authority of the minister of justice. ${ }^{5}$ The

3 See Langbein, Controlling Prosecutorial Discretion in Germany, 41 U. CHI. L. REV. 439 (1974); Wagner, Der objektive Staatsanwalt-Idee und Wirklichkeit, 1974 JURIsTENzEITUNG 212.

4 See E. Schmid, Einführung in DIE Geschichte DER DeUtschen Strafrechtspflege 330-31 (3d ed. 1965); Schram, supra note 2, at 627; Wagner, Zum Legalitätsprinzip, in Festschrift Für DEN 45. DeUtschen JURISTENTAG 149, 15I-60 (1964).

5 K. Davis, supra note 1, at 194-95; K. Peters, Strafrrozess 139-40 (2d ed. 1966) E. Schmid, supra note 4, at 331; Jescheck, supra note 2, at 509. See also West German Court Organization Act $\$$ 141-52. A translation of the sections is included in 10 Foreign PENAL CODEs, supra note 2, at 214-15. 
prosecutor, therefore, does not act as an administrator trying to attain practical goals; instead, his function is limited to the judicial task of applying the provisions of the Penal Code to the facts of each case.

Compulsory prosecution, except where otherwise provided by law, is regarded as a German constitutional requirement based on the equal rights clause. ${ }^{6}$ In addition, the German constitutional concept of the rule of law does not permit broad discretionary power. It is feared that vast discretion would result in local differences in the administration of criminal law and subject the prosecutor to the suspicion that he might be influenced by political motives and considerations of expediency. ${ }^{7}$

Citizens are protected against unjust convictions and oppressive punishment by the Penal Code rather than by individual prosecuting attorneys. This situation is a result of the nineteenth century constitutional movement on the European Continent, which was aimed at limiting the absolute power of the monarch and his administration, and which opposed all deprivations of life, liberty, and property that were not legislatively approved. While the courts in the United States were designed to protect citizens' rights against improper infringement by the government, the Europeans delegated this task to the legislature. Today in the United States court-created procedural and evidentiary safeguards provide protection against improper governmental action; in Europe such protection is considered to be the province of the written statute. Thus there is general agreement in Germany that the Penal Code must be amended, rather than the policies of the prosecutor altered, if the administration of the criminal law produces undesired results. ${ }^{8}$

This concept presupposes a penal code designed to state general principles of responsibility and to include comprehensive, carefully framed, and abstract definitions of offenses and sanctions that are accepted by the general public. The extent to which the German Penal Code meets these requirements can be investigated by examining some examples.

6 Wagner, supra note 4, at 173; Faller, Verfassungsrechtliche Grenzen des Opportunitätsprinzips im Strafprozess, in FESTGABE FÜR THEOdor MAUnz 69, 77-82 (1971).

7 H. Henkel, StrafverfahrensRecht 96 (2d ed. 1968); E. Kern \& C. Roxin, StrafverfatrRensRecht 59 (11th ed. 1972); K. Peters, supra note 5, at 144; Jescheck, supra note 2, at 511; Schram, supra note 2, at 627; Wagner, supra note 4, at 159-60.

8 Wagner, supra note 4, at 159; Baumann, Uber die notwendigen Veränderungen im Bereich des Vermögensschutzes, 1972 JuRrstenzeitung 1, 3-6; Peters, Die Begrenzung des Strafrechts bei zivilrechtlichen Verhältnissen als materiellsrechtliches und prozessuales Problem, in Festschrift FÜr EbERHARD Schmid 488 (1961); Heinitz, Zweifelsfragen des Opportunitätsprinzips, in FESTSCHRIFT Für THEODOR RITTLER 327, 335 (1957). 


\section{Prosecutorial Discretion and the Penal Code}

\section{A. Extensive Judicial Interpretation of Criminal Law}

The German Penal Code defines most offenses in more general and abstract terms than typical American criminal codes. As a result German judges often engage in a great deal of statutory construction, for example when the definition of an offense appears to be so wide as to include conduct not regarded as criminal. Strict construction of penal statutes was never accepted in German law, because it was incompatible with the Code's abstract definitions of crimes.

One example of extensive construction is the interpretation of the provision on breach of trust. ${ }^{9}$ The literal wording of the Code makes it a crime to neglect the duty to manage properly another person's property interests so as to cause damage to them. This provision is too broad, since it covers a simple breach of contract and other activities that obviously should not be called criminal. The courts have therefore defined the meaning of "managing property interests" to include only activities of some importance and independence, where the person concerned is given significant liberty of action and responsibility.10

The prohibition against leaving the scene of a traffic accident ${ }^{11}$ has similarly been judicially restricted. This section forbids people who have been involved in a traffic accident from fleeing to try to avoid identification. The German High Federal Court of Appeals has held that the provision does not apply to a driver of a car who has caused damage only to himself; the court said the purpose of the law is to help injured parties in collecting evidence for a claim of damages, not to aid criminal investigations. ${ }^{12}$ Further, commentators agree that a driver who causes trivial damages to a parked, unoccupied car is not required to remain at the scene of the accident if he leaves his name and address. ${ }^{13}$

Another instance of judicial narrowing of the Penal Code involves

9 Penal Code $\S 266$. An English translation of the Code is published in 4 AMERICAN Series of Foreign penal Codes: The German Penal Code (G. Mueller \& T. Buergenthal transl. 1961).

10 Decisions of the High Court of Appeals of the German Reich [REICHSGERICHT, hereinafter RGSt]: 71 RGSt 90 (1937); 69 RGSt 279 (1935). Decisions of the High Federal Court of Appeals of the Federal Republic of Germany [BUNDESGERICHTSHOF, hereinafter BGHSt]: I BGHSt 186 (1951); 4 BGHSt 170 (1953). See also R. MaUrach, DeUtsches STRAfrecht, BESONDERER TEIL 343-45 (5th ed. 1969).

11 Penal Code $\$ 142$.

128 BGHSt 263 (1955).

13 R. MAURAch, supra note 10, at 716; A. SGHönke \& H. Schröder, STRAFgesetzBuch, § 142, annot. No. 35 (16th ed. 1972). Where the damage is not trivial, the length of time a driver must wait for other parties to show up is not fixed by the Code, but depends upon the facts of each case. R. MAURACH, supra note 10, at 716; A. SCHÖNKE \& H. SchrödER, supra, annot. Nos. 39-38. 
the law of defamation. ${ }^{14}$ Although there is no basis for such an exception in the statutory language, defamatory remarks made to a third person are not punished if made among family members or close friends. ${ }^{15}$ Similarly, the provision on abandonment is too broad; it includes anyone who abandons a person charged to his care who is helpless because of youth, infirmity, or illness. ${ }^{16}$ Parents who leave their small children alone in the house for an evening would be guilty of an offense for which they could be sentenced to imprisonment for not less than three months. It is generally agreed that this section is violated only if the abandonment endangers the victim's life or limb. ${ }^{17}$

These examples show that German law relies on careful and elaborate judicial interpretation of the substantive law to solve problems that the United States often leaves to the discretion of the prosecutor. Judicial interpretation of substantive law is successful, however, only if the definitions meet certain minimum requirements. For example, in the 1950s the German Penal Code defined some of the political offenses by extremely vague terms. The Federal Attorney General in charge of prosecuting the more serious political offenses argued that the substantive law of political crimes could not be reconciled with the rule of compulsory prosecution. He stated that the sweeping definitions of the Penal Code necessitated broad discretionary power for the prosecuting attorney. 18

The doctrine of extensive judicial construction is also used to broaden the definition of an offense if the interests of justice so require. For instance, in the provision on dangerous assault, "by means of a weapon" is interpreted to include the throwing of hydrochloric acid into the victim's face ${ }^{19}$ and the setting of a dog. ${ }^{20}$ In the definition of robbery, "by force" includes nonviolent narcotization of the victim. ${ }^{21}$

The abstract definitions in the Code obviously create the potential for a good deal of prosecutorial discretion. Prosecutors are, however, usually hesitant to take advantage of this discretionary power by deciding doubtful cases themselves. In close cases they prefer to prosecute and leave to the judiciary the function of deciding open questions and

14 Penal Code $\$ \$ 185$ et seq.

15 R. MAurAch, supra note 10, at 138-39; A. SChöNKE \& H. SCHRöDER, supra note 13 , $\S 185$, annot. No. 8 .

16 Penal Code § 221.

1721 BGHSt 44 (1966); R. MAURACH, supra note 10, at 48.

18 M. GÜDE, Probleme des POLITISChEN STRAFrechrs 23 (1957). See also Schram, supra note 2, at 631 .

19 Penal Code $\$ 223 a$. 1 BGHSt 1 (1950).

2014 BGHSt 152 (1960).

21 Penal Code § 249; 1 Bghst 145 (1951). See also S. Kadish \& M. Paulsen, Criminat LAW AND ITs Processes 46 (2d ed. 1969). 
clarifying the definitions of offenses..$^{22}$ The German High Federal Court of Appeals has stated this principle more forcefully; it held that prosecutors must strictly follow the court's decisions in interpreting the Code. ${ }^{23}$ This statement was surprising because, in civil law countries, court decisions are regarded not as sources but as interpretations of the law. Accordingly, the holding of the High Federal Court of Appeals was widely repudiated..$^{24}$ It was said that the idea of compulsory prosecution cannot be taken to exclude the prosecutors' right to interpret the law, since they function as an independent agency of the judiciary. The extent to which they actually exercise this right is another question.

\section{B. Lenient Sentencing Policy}

Another factor favoring limited prosecutorial discretion is that sentences in Germany are considerably less severe than in the United States. Professor Zeisel, familiar with the criminal law systems in both countries, has suggested that a one-month prison sentence may be imposed in European countries for crimes that would result in imprisonment for one year in America. ${ }^{25}$

Mandatory minimum sentences provided in the German Penal Code are generally more lenient than in American codes. This fact is particularly true where a criminal defendant has previously been convicted of a crime. While a number of American states require lengthy imprisonment for recidivists, ${ }^{28}$ German law sets the minimum at only six months for third convictions when the defendant has been in jail before and "failed to heed the warning of the prior sentences."27 Only habitual criminals who have previously been convicted of serious crimes and twice have been imprisoned for a year, may be placed in protective custody for an unlimited time if necessary for the safety of the community. ${ }^{28}$ The differences in sentencing are even more clearly demonstrated by the average sentencing practices in each country. In America, "[m]ore than one-half of the adult felony offenders sentenced to state

22 See K. Davis, supra note 1 , at 194.

2315 BGHSt 155 (1960).

24 E.g., K. PeTERs, supra note 5, at 144-45; E. KeRN \& C. RoxIN, supra note 7, at 44-45.

25 Zeisel, Die Rolle der Geschworenen in den USA, 21 OSTERREICHISChE JURISTENZEITUNG 121, 123 (1966). See also Clark, The Courts, the Police and the Community, 46 S. CAr. L. REv. 1, 4 (1972).

26 ABa Project on Minimum Standards for Criminal Justice, Standards Relating to Sentencing Alternatives and Procedures 164 (1967); The Habitual Criminal-A Comparative Study, 13 McGill L.J. 652 (1967).

27 Penal Code \& 17. German law on recidivism was changed in 1969; previously, there were several provisions dealing with recidivists. See, e.g., id. \& 20a (dangerous habitual criminals); id. § 244 (repeated property offenses).

28 Id. \$ 42e. This provision was also changed in 1969. 
prisons in 1960 were committed for maximum terms of 5 years or more; almost one-third were sentenced to terms of at least 10 years." 29 In Germany in 1970, over 60 percent of the prison sentences were for less than six months, and most of those sentences were suspended. ${ }^{30}$

German judges generally impose sentences that are close to the mandatory minimum. ${ }^{31}$ The Penal Code also allows sentences below the minimum punishment for some serious offenses if mitigating circumstances are found.32 Judges often reduce sentences not because such circumstances exist, but merely because a less severe sentence seems appropriate. ${ }^{33}$

Reduction of charges and plea bargaining in the United States, which would be impossible without wide prosecutorial discretion, are to a great extent intended to avoid excessively harsh sanctions. The problems created by the severe sentences in America do not exist in Germany, thus removing one reason to grant broad discretion to the prosecutor.

\section{Instances of Prosecutorial Discretion}

Compulsory prosecution is the general rule controlling the German prosecutor's activities whenever felonies and serious misdemeanors are involved. ${ }^{.4}$ Felonies such as murder, robbery, rape, perjury, and arson are prosecuted if there is sufficient evidence to prove the defendant's guilt. Compulsory prosecution in these cases is considered necessary because of the serious character of the offenses. German lawyers agree that the interests of justice, as well as deterrence, require equal prosecution of serious crimes.

The rule of compulsory prosecution sometimes leads to extreme consequences. In one case, a young man took two apples from a display outside a store; the storekeeper asked him to return the apples, and the young man resisted with force. The use of force to defend stolen goods is a felony under the German law. Thus the prosecutor had to file a

29 Presidential Commission on Law Enforcement and the Administration of Justice, TASK FORCE REPORT, THE COURTs, at 17 (1967).

30 H. Jeschecr, Lehrbuch des Strafrechts-Allgemeiner TeiL 22 (2d ed. 1972).

31 K. Rolinskr, Die Prägnanztendenz im Strafurteil 81 (1969); J. Schiec, Unterschiede IN DER DEUTSCHEN STRAFRECHTSPRECHUNG 25-27 (1969). Except during the Nazi period, this tendency has steadily strengthened since the enactment of the Penal Code in 1871.

32 See, e.g., Penal Code $\S 154$ (perjury), 217 (infanticide), 228 (certain cases of assault), 249 (robbery).

33 F. EXNER, Studien ÜBer die Strafzumessungspraxis der deutschen Gerichte 20-23, 84-85 (1931); K. RoLINSKr, supra note 31, at 82; J. SchIEL, supra note 31, at 24.

a4 For a definition of the categories of crimes under the Penal Code, see text and note at note 77 infra. 
charge, and the young man was convicted. ${ }^{35}$ In another case, a police officer had collected fifteen German marks ${ }^{36}$ for traffic fines on a Friday night. He spent the money during the weekend, but he intended to turn over fifteen marks when he reported to duty the following Tuesday; there was no doubt that he had sufficient means to do so. Nevertheless, the police officer was charged with and convicted of aggravated embezzlement in office. This offense is a felony, so the prosecutor was compelled to prosecute. ${ }^{37}$

Despite the strong emphasis placed on compulsory prosecution, the German prosecutor has always exercised certain types of discretion. The next part of this article will discuss the situations in which prosecutorial discretion exists.

\section{A. The Power to Pass on the Sufficiency of the Evidence}

The prosecutor will only bring a charge when he determines that sufficient evidence exists to obtain a conviction. Even when the rule of compulsory prosecution applies, he can close the case if he concludes that the evidence will probably not support a conviction. ${ }^{38}$ In practice, most investigations are terminated in this way. ${ }^{39}$ In doubtful cases, however, prosecutors generally hesitate to use this discretionary power. They realize that they are familiar with the case merely from the files, and a judge at the end of a trial will be in a better position to decide the defendant's guilt.

There are, however, exceptions to this general rule. A middle-aged

353 BGHSt 76 (1952).

30 One German mark is currently worth about 40 American cents.

37 Decision of the High State Court of Appeals of Cologne, 1968 NEUE JURISTISche WochENSCHRIFT 2348. In the late 1920s, a public officer who had taken 20 German pennies was charged with simple theft in office (today 20 West German pennies would be equivalent to less than 10 American cents). Although the offense was only a misdemeanor, the prosecuting attorney did not use the fact that a small amount was involved to discontinue proceedings. He was apparently moved to prosecute because a public officer was involved. Decision of the Highest State Court of Appeals of Bavaria, 87 GoltDammer's ARCHIV FÜR STRAFRECHT 130 (1927).

38 Code of Criminal Procedure $\S 170$. See also K. Davis, supra note 1, at 194; E. Scrmidr, Lehroommentar zUR STrafprozessordnUNg UNd zUM Gerichtssverfassungsgesetz, TeII I, 386 (2d ed. 1964); Jescheck, supra note 2, at 511.

39 H. Dahs, Handbuch des Strafverteidigers 154 (3d ed. 1971); K. Peters, supra note 5, at 88. In 1971 in Bade-Württemberg, one of the West German states, prosecutors discontinued 50 percent of the proceedings because of insufficient evidence. Blankenburg, Die Staatsanwaltschaft im Prozess sozialer Kontrolle, 5 KRIMINorocisches Journal 181, 182 (1978). The actual practice varies among the local offices. In Bade-Württemberg, for example, one office discontinued 61 percent of the proceedings for insufficient evidence, while another office did so in only 45 percent of its cases. Blankenburg, $i d$. at 183. The comparison is somewhat distorted because of differences in record keeping. 
man, who had a son in his early twenties from a former marriage, married a young girl. Son and stepmother had sexual relations, and the father reported them to the police. Intercourse between in-laws is a crime according to German law; ${ }^{40}$ the defendants had unquestionably committed the act and ordinarily a charge would have been brought. The prosecuting attorney, who was known among his colleagues for his readiness to terminate investigations, questioned the two young people separately and asked whether they had known that their act was illegal. Both answered in the negative, and the prosecutor dropped the investigation for insufficiency of evidence. Under German law, they could have been convicted only upon proof that their ignorance of the law was avoidable. ${ }^{41}$ The prosecutor did not, however, attempt to procure evidence that the young people could have known the illegality of their conduct.

The prosecuting attorney who considers discontinuing an investigation frequently must decide whether further investigations will reveal additional evidence. This question is particularly important in cases of white collar crimes involving complex business transactions, or where a minor crime has been only routinely investigated. Compulsory prosecution demands thorough investigation of every case, but the chances of finding new evidence must be carefully evaluated; it is obviously permissible for the prosecutor to avoid futile inquiries.

A prosecuting attorney who knows that he has sufficient evidence for a charge, but fails to prosecute, can be charged with favoritism. ${ }^{42}$ This law is intended to guarantee the operation of the rule of compulsory prosecution; prosecutions for favoritism are, however, quite rare. ${ }^{43}$ With regard to police officers, also covered by the provision on favoritism, the German High Federal Court of Appeals has held that the duty to prosecute should not exceed the working capacity of the officer concerned. ${ }^{44}$

The prosecutor's decision not to investigate, or not to investigate further because of insufficient evidence or because there was no violation of law, is not necessarily the end of a case. The victim, if he has reported the crime, can file a formal complaint within a one-month

40 Penal Code $\S 173$ (incest).

41 See Ryu \& Silving, Error Juris: A Comparative Study, 24 U. CHr. L. REv. 421, 448-58, 461-65 (1957).

42 Penal Code \$ 346.

43 German official statistics combine the offenses of favoritism, id. § 346 , and permitting prisoners to escape, id. $\S 347$. In 1970, for both offenses, a total of eight cases are reported. Four defendants were convicted, one was acquitted, and in three cases proceedings were terminated by the courts without a decision on the defendant's guilt. See Statistisches Bundesamt, BevölKerung und Kultur, ReiHe 9: RechtspFlege 1970, 42 (1972).

4418 BGHSt 19 (1960). 
period. ${ }^{45}$ The attorney general, the chief prosecutor in the state, ${ }^{46}$ reviews the prosecutor's decision by examining the file for that particular case; he is empowered to direct the prosecutor to reopen the investigation and file charges, but this action is rarely taken. Because of the availability of these procedures, the prosecutor seems to be somewhat more reluctant to discontinue an investigation when there is a victim who can bring such a complaint.

A victim whose formal complaint is rejected can file a motion with the highest state court of appeals asking that the prosecuting attorney be directed to file a charge. ${ }^{47}$ This judicial review is intended to be a safeguard against prosecutorial abuse of power and is regarded as an important means for the citizen to enforce the rule of compulsory prosecution. The opportunity for judicial review is rarely seized, partly because the victim must pay his legal fees and the court costs if his motion is denied. ${ }^{48}$

In addition to the formal complaint, the victim can also attack the prosecutor's decision to stop investigating a case by filing a departmental complaint. ${ }^{49}$ The departmental complaint is directed to the prosecutor's superior and accuses the prosecutor who closed the case of malfeasance. The prosecutor must explain his reasons for terminating the investigation, and the superior's decision is based on the file maintained by the prosecutor. If the superior concludes that the prosecutor's decision was incorrect, the investigation is reopened. Departmental complaints are often filed, but they have been successful only in a few cases in which new evidence was introduced by the victim.

In practice, control over the prosecutor's decisions is exercised through close supervision and cooperation in the local prosecution office. The head of the local office and the supervisors of its various sections control the work of their subordinates by personal contacts and review of the files. Regular conferences are held to discuss individual cases and to work out general patterns for structuring prosecutorial discretion. To close any case, the prosecutor must obtain the approval of his superior. Above the local level, cooperation among prosecutors is less extensive; personal contacts are infrequent and meetings to discuss law enforcement problems rarely occur.

45 For details of this procedure, see Jescheck, supra note 2, at 512 and Langbein, supra note 3 , at $463-65$.

46 The Federal Attorney General is responsible for prosecuting few cases involving political matters. See Jescheck, supra note 2, at 512.

47 Code of Criminal Procedure $\$ \$ 172-75$.

48 Id. § 177.

40 For details of this procedure, see Jescheck, supra note 2, at 512 and Langbein, supra note 3, at $465-66$. 
A prosecutor who has decided that the evidence in a case is sufficient to obtain a conviction cannot always prosecute. Some criminal offenses can be prosecuted only after the victim has filed a motion for prosecution. ${ }^{60}$ These offenses involve primarily violations of personal interests, such as breach of domestic peace, defamation, seduction of a girl younger than sixteen, abduction of minors or females, causing bodily harm, domestic theft and fraud, unauthorized use of a vehicle, and damage to property. ${ }^{51}$ The victim in these cases is given an option to file a motion and have the offender prosecuted or not file and thereby protect his personal affairs from the intrusion of a police investigation and the publicity of a trial.

\section{B. Offenses Subject to Private Charge by the Victim}

Another instance of prosecutorial discretion is found in connection with the victim's right to prefer a private charge..$^{52}$ The German Code of Criminal Procedure provides for private prosecution in cases of breaching domestic peace, insult, causing bodily harm, threatening with a serious crime, violating the secrecy of the mails, causing damage to property, and violating copyright laws and laws against unfair competition. ${ }^{53}$ The common characteristic of these offenses is not their triviality, but the predominantly personal character of the interests involved. Thus the victim is permitted to assume the role of a prosecutor and bring the offender to trial; the procedural rules in private prosecutions are essentially the same as in public prosecutions. ${ }^{54}$ As late as the 1950s private charges for cases involving insults were not unusual, but today they have become an exception. ${ }^{55}$ Victims of an offense obviously prefer to report it to the police or to the prosecuting attorney in order to have their case investigated by public authorities.

The prosecutor is authorized to file a public charge in cases subject

50 FOREIGN OFFICE, supra note 2, at 94-95; Jescheck, supra note 2, at 514; Wolff, supra note-2, at 1078. The motion for prosecution must be filed within three months either with the police, the prosecutor's office, or a court. Penal Code $\$ 61$; Code of Criminal Procedure $\S 158$. The three-month period begins when the victim learns of the offense and ascertains the identity of the offender.

51 For some offenses, the victim may file a private charge. See text and notes at notes 52-61 infra. For certain offenses involving bodily harm, a "special public interest" in prosecution may replace the victim's motion. See text and notes at notes $62-67$ infra.

62 FOREIGN OFFICE, supra note 2, at 154; Jescheck, supra note 2, at 513; Wolff, supra note 2, at 1077 n.23.

53 Code of Criminal Procedure $\$ 374$.

54 See id. $\$ \S 374-94$.

55 As to the former practice, see Wolf, supra note 2, at 1077 n.23. Today in one South German court district with 300,000 residents, there are approximately 50 private prosecutions per year. 
to private prosecution only if it is in the "public interest." ing of the public interest requirement is explained in the Uniform Rules of Criminal Procedure. ${ }^{57}$ Rule 76 states that generally the public interest is involved if the particular violation affected people in addition to the victim and if the prosecution is of public concern because of the severe, brutal, or dangerous character of the offense, the motives of the offender, or his position in public life.

Despite its vague language, Rule 76 has to some extent controlled prosecutorial discretion. For example, insignificant quarrels and fights among neighbors or insults exchanged by automobile drivers are ordinarily left to private prosecution. But when a former German chancellor was publicly slapped in the face by a woman who disapproved of his activities during the Nazi period, a public charge was brought. Public prosecution was also initiated when a lawyer called a witness a shameless liar in open court and when a police officer insulted an automobile driver who, after being stopped for speeding, interferred with the checking of other vehicles. ${ }^{58}$ Prosecutors generally do not take action in cases of minor bodily injuries caused within the family, but the public interest is deemed to require prosecution if a father terrorizes his family or a child is physically abused. Simple assaults during barroom brawls are not viewed as important enough to require a public charge; the decision would be different, however, if an organized gang molested diners in restaurants.

The offenses that can be prosecuted by private persons are also included in the group of crimes for which a public charge may be brought only upon the victim's motion. As a result, a prosecuting attorney who believes that the public interest requires a public prosecution cannot do anything if the motion is not filed. ${ }^{59}$ The rule of compulsory prosecution is supplanted by the principle that the ultimate decision to prosecute in these cases should be made by the victim. If the prosecutor

56 Code of Criminal Procedure $\$ 376$. Where proceedings by the victim have been initiated, the prosecutor can assume control of the case, placing the victim in the position of an intervenor. See id. $\S 377$; ForeigN OfFice, supra note 2 , at 154.

57 These rules were administratively promulgated by the states to give guidelines for deciding technical procedural questions and to structure the exercise of prosecutorial discretion. They are not, however, legally binding. The text of the Rules is set forth in T. KLeINKNecht, Strafrrozessordnung, Appendix F 1, "Richtlinien für das Strafuerfahren und das Bussgeldverfahren," 1525-1673 (31st ed. 1974). See also E. KFRN \& C. ROXIN, supra note 7 , at 12 .

58 See K. Homann, Der Begriff des "öffentlichen Interesses" in den $\S \S 376,153$ StPO und $\S 232 \mathrm{StGB}$ at 70-72 (doctorate thesis, University of Göttingen, 1971).

69 In some cases involving bodily harm, a "special public interest" in prosecution may replace the victim's motion. See text and notes at notes 62-67 infra. 
decides, however, that the public interest does not require public charges, the injured party has no right to appeal his decision. In some cases the victim has tried to persuade the prosecutor to assume control of the case, because public prosecution involves less effort and risk for a private citizen..$^{60}$ If the prosecutor is unwilling, the victim might file a departmental complaint, but such complaints are rarely successful. ${ }^{01}$

C. The Special Public Interest Requirement in

Cases Involving Bodily Harm

In cases involving intentional infliction of bodily harm or negligently causing bodily harm, ${ }^{62}$ public charges may be brought only upon motion by the victim, unless official intervention is deemed necessary by reason of "special public interest." 33 The requirement of "special" public interest is a stricter standard than the public interest standard applicable to offenses that are subject to private prosecution. ${ }^{64}$ Again, the Uniform Rules of Criminal Procedure provide guidance for the prosecutor's discretionary determination. ${ }^{65}$ A special interest in public prosecution exists if the offender was previously convicted of a similar crime, if he acted recklessly, or, in the case of a traffic accident, if the driver was under the influence of alcohol or caused serious harm. The prosecutor should also consider whether the victim is interested in prosecution and whether the offender or a relative was injured in the accident.

Prosecuting attorneys maintain that they consistently try to comply with the Rules. In fact, they generally find special public interest, and exceptions are made only in trivial cases. For example, public charges have been brought when industrial safety laws were neglected, when a meat ptocessing firm sold tainted products, and when the victim in a traffic accident was hospitalized or unfit to work. Cases involving only minor bruises or sprains were not deemed important enough to bring a public charge. ${ }^{66}$

\footnotetext{
60 See Jescheck, supra note 2, at 513.

61 See text at note 46 supra. A formal complaint cannot be filed in cases subject to private prosecution.

62 Under German criminal law, ordinary negligence is a sufficient basis for criminal responsibility.

63 Penal Code \$ 232. See also Jescheck, supra note 2, at 513-14. The special interest clause was added to the Penal Code in 1940, primarily because increasing road traffic had led to the conclusion that prosecution of traffic accidents involving bodily injuries should not depend on a discretionary determination by the victims.

64 K. LACKNeR \& H. MAASSEN, Strafgesetzbuch $\S 232$, annot. No. 4 (7th ed. 1972); H. Müller \& W. SAX, Kommentar zUR Strafprozessordnung § 376, annot. No. 1 (6th ed. 1966); Oehler, Die amtliche Verfolgung der leichten vorsätzlichen und fahrlässigen Körperverletzung, 1956 JURISTENZETTUNG 630.

65 Uniform Rules of Criminal Procedure 259, 272.

66 See examples in text following note 58 supra. See also K. Homann, supra note 58, at $87-91$.
} 
The offender who is charged with causing bodily harm cannot appeal the prosecutor's decision that there is a special public interest requiring an investigation. Further, the prosecutor's exercise of this discretionary power is not reviewable by the courts. ${ }^{67}$ In these cases, the departmental complaint procedure is the only available remedy.

\section{Petty Infractions and Prosecutorial Discretion}

German law distinguishes criminal offenses from petty infractions not involving the high degree of moral guilt considered necessary to justify a penal sanction. ${ }^{68}$ Petty infractions are comparable to violations considered mala prohibita in American law, such as violations of traffic laws, trade and business regulations, and laws protecting the health and safety of citizens. Unlike mala prohibita offenses, however, petty infractions require intent or negligence for conviction. ${ }^{69}$ The sanctions provided for petty infractions are regulatory fines instead of the harsher penalties of the Penal Code..$^{70}$ The prosecution of petty infractions and imposition of sanctions are the province of administrative authorities; the judiciary is not involved. Investigation and prosecution of the offenses are governed by considerations of expediency rather than the rule of compulsory prosecution, and broad discretion is given the authorities. ${ }^{71}$ For example, in cases involving traffic violations-by far the most frequent petty infraction-the police decide whether to institute proceedings and whether pending proceedings should be terminated. The only limit on discretion is the prohibition against arbitrariness and abuse of power. ${ }^{72}$

The prosecuting attorney becomes involved in such cases only if a defendant files a complaint against an administrative order imposing a regulatory fine. The complaint must be filed with the authority that issued the order, but is forwarded to a prosecutor who takes it into court for a judicial decision..$^{73}$ While the case is not yet before the court, the prosecutor, like the administrative agency, is authorized not to prosecute. Before closing a case, however, he should check with the

6716 BGHSt 225 (1962); K. LACKNER \& H. MAASEN, supra note 64, § 232, annot. No. 4. But see A. SCHöNKE \& H. SCHRöDER, supra note 13, § 232, annot. No. 3.

68 See E. GöhLler, GESETZ ÜBer ORDNungswidRigkeIten 10-12 (1970); H. Jescheck, supra note 30 , at 40 .

69 As in criminal offenses, ordinary negligence is a sufficient basis for responsibility. See note 62 supra.

70 Petty Infractions Code [OrDnUngswidRigkerrenGESETz] $\S 13$, sets the maximum regulatory fine at 1000 German marks (presently equivalent to about $\$ 400$ ), but allows for higher sums whenever authorized by another statute. Thus fines may be as high as 100,000 German marks. See E. GöHLER, supra note 68, at 901-44.

71 Petty Infractions Code § 47.

72 E. GöHLER, supra note $68, \S 47$, annot. No. 2.

73 Petty Infractions Code $\$ \S 67-69$. 
original authority to be sure that his decision is consistent with the policies followed by the administrative agency. ${ }^{74}$ Contacting the authority is not required either if the decision depends solely on a question of law that the prosecutor can decide without an administrative expert or if the prosecuting attorney is sufficiently familiar with the questions of fact involved. ${ }^{75}$

In fact, prosecutors rarely discontinue prosecutions of petty infractions. Most of the filtering of cases is done at an earlier stage by the administrative authorities. Prosecutors generally agree that after a complaint is filed, a judge should make the final decision. ${ }^{76}$ Prosecutors are ready to consider termination of the proceedings only when the order issued by the administrative agency obviously resulted from an error of law or when new evidence is introduced by the complainant.

\section{E. Petty Misdemeanors and Prosecutorial Discretion}

The German Penal Code places criminal offenses into three categories: felonies (punishable by imprisonment for at least one year); misdemeanors (punishable by imprisonment or a fine); and petty misdemeanors (punishable by imprisonment up to six weeks or a fine not exceeding five hundred marks). ${ }^{77}$ The category of petty misdemeanors is steadily shrinking, as many of them are reclassified into petty infractions. ${ }^{78}$ This reclassification has been prompted by the belief that the administrative procedure used for petty infractions ${ }^{79}$ best satisfies modern needs for speedy and flexible enforcement of the type of laws formerly in the petty misdemeanor category. The new General Part of the German Penal Code, to become effective on January 1, 1975, abolishes the petty misdemeanor category.

Prior to 1924, the Code of Criminal Procedure required the prosecuting authorities to investigate even the most trivial offenses, but in fact almost everyone admitted that the police took action only in important cases. $^{80}$ The economic depression of the early 1920s in Germany created

74 Uniform Rules of Criminal Procedure 328, 338.

$75 I d$. For instance, prosecutors in the traffic section of the prosecution office usually do not need the advice of a police officer to decide a traffic case.

76 The judge, instead of deciding the issue of guilt, can close the case with the prosecutor's consent. Petty Infractions Code $\$ 47(2)$.

77 Penal Code $\S 1$.

78 In 1969, for example, traffic violations were removed from the petty misdemeanor class and are now treated as petty infractions. The most common remaining petty misdemeanors are petty pilfering, causing noise or gross mischief, and acts of public obscenity. 79 See text and notes at notes 68-72 supra.

80 A. Graf zu Dohna, Das Strafprozessrecht 68 (3d ed. 1929); B. Drews \& G. Wagke, ALlgemeines Polizetrecht 158 (7th ed. 1961). 
pressures to simplify and speed the criminal processes, ${ }^{81}$ and a provision was added to the Code of Criminal Procedure giving the prosecutor and police authorities discretionary power not to prosecute a petty misdemeanor where the guilt of the offender is minor and the public interest does not require a judicial decision. ${ }^{82}$ The Uniform Rules of Criminal Procedure state that the public interest requires prosecution of a petty misdemeanor if it is committed with exceptional frequency or if the accused has previously been convicted of similar offenses. ${ }^{83}$

In practice, most petty misdemeanors are never considered by the prosecutor, because the police do not begin investigations. The prosecutor deals only with cases that the police consider important enough to be prosecuted. These cases have been carefully screened by the police, ${ }^{84}$ so there is usually no reason for the prosecutor to fail to prosecute.

One situation in which public charges are typically brought for a petty misdemeanor is the theft of small quantities of food from supermarkets. ${ }^{85}$ The prevalence of this type of offense has led the police and prosecutors to consider punishment a necessary means of deterrence. Exceptions have been made in a few circumstances, however, such as an indigent person taking a loaf of bread or an elderly woman who presented a doctor's report stating that she had emotional problems. Prosecutions are also sometimes brought for causing noise or gross mischief. For example, a group of juveniles were prosecuted for holding meetings in a public place with the engines of their motorbikes running, and some students were prosecuted for tampering with street signs and tipping over garbage cans. ${ }^{86}$

The prosecutor does not encounter many situations where the discretionary power granted to enable him to deal with petty misde-

81 See Wolff, supra note 2, at 1078. See also J. KRÜMPELMANN, DIE BAgnteILdDELIKTE 203-04 (1966).

82 Code of Criminal Procedure § 153(1). See Jescheck, supra note 2, at 513-14.

83 Uniform Rule of Criminal Procedure 83(1). See also id. 82.

84 One court has held that the police must present all petty misdemeanors reported by a citizen to the prosecutor. Decision by the Highest State Court of Appeals of Bavaria, 1966 Juristenzeitung 149. See also I LöWe-Rosenberg, Die Strafrozessordnung und das GerichtSVERFASSUNGSGESETz: GrossRomMENTAR § 153, annot. No. 11 (22d ed. 1971); H. MÜLLER \& W. SAX, supra note $64, \S 153$, annot. No. 1 . There is good evidence that this holding is frequently ignored. See the numerous examples presented in J. FEEST \& $\mathrm{E}$. Blankenburg, Die Definimonsmacht der Polizer 58-113 (1972).

86 For a discussion of the theft of larger quantities of food or other goods, see text at note 102 infra.

86 Kohlhaas, Unzulässige Durchbrechung des Legalitätsprinzips, 1956 GoLTDAMMER's ARCHIV FÜr STRAFrECHT 241, 247 (listing the reckless making of noise in the vicinity of hospitals and schools as cases that should be prosecuted). 
meanors is appropriate. In practice, the job of exercising discretion in these cases is performed by the police.

\section{F. Prosecutorial Discretion in Misdemeanor Cases}

Prosecution of misdemeanor cases may be terminated by the prosecutor with the court's consent, if the guilt of the offender is minor and prosecution is not required by the public interest. 87 The German category of misdemeanors is broad and includes many crimes that would be considered felonies under American law, such as larceny, embezzlement, fraud, extortion, receiving stolen goods, forgery, negligent homicide, abortion, inflicting bodily harm with a weapon, false imprisonment, dangerous driving, bigamy, and incest. This wide range of offenses in which the prosecutor can exercise discretion, subject to court approval, might give the impression that his discretion is not very limited. It must be remembered, however, that prosecutors regard compulsory prosecution and restraint of discretion as overriding principles. They generally agree that they should be reluctant to exercise their discretionary power, and they abort proceedings only in really trivial cases. ${ }^{88}$

Unlike the prosecutor, police authorities in misdemeanor cases are given no discretion by the Code of Criminal Procedure. ${ }^{89}$ Police officers must investigate all reports of misdemeanors. To what extent they comply with this requirement is a difficult question. A recent study revealed astonishing instances involving the exercise of discretion by the police in misdemeanor cases. ${ }^{90}$ Indeed, a leading authority on criminal procedure has argued that the police should not be required to investigate insignificant matters. ${ }^{91}$

Prosecutors must often decide whether guilt is minor and public interest non-existent before they have fully investigated a case. Some commentators contend that any decision to close a case should be made only after gathering all of the available evidence. ${ }^{92}$ In fact, prosecutors tend to close a case if there is a strong probability that further investigations

87 Code of Criminal Procedure § 153(2); see Jescheck, supra note 2, at 514.

$88 \mathrm{~K}$. Peters, supra note 5, at 508; Dahs, Der Anwalt im Strafprozess, 9 Anwaltsblatt 171,182 (1959). Blankenburg, supra note 39, at 182, indicates that in 1971 in BadeWürttemberg less than 4 percent of all cases were dropped because the offense was insignificant and prosecution was not required by the public interest. Generally prosecution offices follow the same trend, but Blankenburg, id. at 183, notes that there is some variance. One office, for example, discontinued about 2 percent of the cases, while another did so in 15 percent. Differences in record keeping account for some of the variances.

89 Section 153(2) of the Code refers only to the "prosecution," that is, the prosecutor.

$80 \mathrm{~J}$. FeEsT \& E. BLANKEnBurg, supra note 84, at 58-113.

91 H. Müller \& W. SAX, supra note $64, \S 153$, annot. No. 3.

92 J. KRüMPELMANN, supra note 81, at 208; 1 LöWE-ROSENBERG, supra note 84, § 153, annot. No. 8; H. MülLER \& W. SAX, supra note 64 , § 153, annot. No. 2(d); Kohlhaas, supra note 86 , at 242 . 
would reveal only minor guilt.93 A different approach would frustrate the purpose of the provision that authorized the termination of prosecution-to bring relief to overburdened prosecutors and enable them to concentrate on more serious cases. ${ }^{94}$

A further complication is the difficulty in determining whether a particular offender's guilt may be called minor, and public interest may be deemed nonexistent. The Uniform Rules of Criminal Procedure do not provide much guidance for these decisions in misdemeanor cases. To determine whether the offender's guilt may be deemed minor, the Rules advise the prosecutor to compare the case with similar cases involving the "average" amount of guilt. ${ }^{25}$ The Rules also suggest that, before dropping a misdemeanor case, prosecutors consult with the administrative authorities that either reported the offense or are otherwise interested. ${ }^{\circ 6}$

The prosecutors usually do not make a great effort towards precisely following vague terms like public interest and minor guilt. Instead they try to develop patterns of interpretation and to ensure that similar types of offenses are treated in the same manner. Some examples will show how this process operates; at the same time, they will demonstrate the workings of the principle of restrained discretion in German criminal procedure.

Driving a motor vehicle without a license, a misdemeanor in Germany, ${ }^{97}$ is ordinarily deemed too dangerous to the public to justify a failure to prosecute. But when, for example, a farmer's teenage son operated a tractor without a license on public roads to reach a nearby field, prosecutors were inclined not to prosecute and the courts almost always consented. They understood that farmers with small farms may be unable to pay farmhands and must allow their sons to drive; therefore, the guilt in these cases was deemed minor and there is no significant public interest. The prosecutor's decision might be different, however, if tractor driving by young children became sufficiently widespread.

A case prosecutors often face is that of a father who is unwilling to

93 Compare the similar problem in connection with the prosecutor's decision as to the sufficiency of the evidence. See text in the paragraph following note 41 supra. See also H. MüLLER \& W. SAX, supra note 64, § 153, annot. No. 2(d); T. KLEINKNECHT, supra note 57 , § 153, annot. No. 2(A).

94 J. KrüMpelmann, supra note 81, at 203-04; Wolf, supra note 2, at 1078.

95 Uniform Rule of Criminal Procedure 83(3). See also J. KRÜMPELMANN, supra note 81, at 208; 1 Löwe-Rosenberg, supra note $84, \S 153$, annot. No. 3.

96 Uniform Rule of Criminal Procedure 83(2). This is intended to alert them to one aspect of possible public interest. In addition, the Rules give the simple-minded advice that all of the facts of the case should be considered. $I d .83(3)$.

o7 Road Traffic Act [STRASSENVERKEHRSGESETZ] § 21. 
pay for the support of his family or an illegitimate child. ${ }^{98}$ The public interest requires prosecution of such a breach of duty, at least to protect the community from financial burdens. If the investigation reveals, however, that the defendant has begun to pay and intends to continue payments in the future, the prosecutor, with consent of the court, often closes the case. The family's or child's interest in regular support is given preference over the public interest in punishment.

In some cases a prosecutor has declined to prosecute negligent homicide. ${ }^{99} \mathrm{~A}$ fatal traffic accident, for instance, might be primarily caused by the victim, and the defendant's guilt might be minimal. A charge of negligent homicide was brought, however, in the following case. A public playground that was opened near railroad tracks was enclosed by bushes instead of a fence. A mother neglected to pay attention to her young child in the playground; the child crawled through the bushes, went on the railroad tracks, and was killed by a train. Action was taken against the city official in charge of planning playgrounds. The prosecutor decided to prosecute, because he deemed the public interest important enough that a judge should decide the question of guilt..$^{100}$

German prosecutors agree that abortion is a misdemeanor that should always be prosecuted. Until 1969 abortion, except when performed by the pregnant woman, was a felony and thus had to be prosecuted without exception. The present prosecutorial attitude is perhaps influenced by the previous classification. In deciding whether to prosecute an abortion offense, prosecutors refuse to consider the vigorous movement for liberalized abortion laws, statements by members of parliament advocating liberalization of the law, or that women with sufficient money travel to England, the Netherlands, or Switzerland to have abortions. Prosecutors state that the rule of compulsory prosecution demands enforcement of the abortion laws until they are repealed.

Despite this general rule, there have been two important instances of prosecutorial inactivity. In the troubled times soon after World War II numerous girls were raped, and some doctors terminated resulting pregnancies in spite of the fact that abortions are permitted only to save the mother's life or health. Investigations were launched against some of these doctors, but in this special post-war situation, the top prosecutorial authorities agreed that no charges should be brought if

98 Penal Code § 170(2). See also K. Homann, supra note 58, at 95.

$99 \mathrm{~J}$. KRÜMPELMANN, supra note 81, at 210 .

100 At trial the official was found guilty of negligent homicide and ordered to pay a fine; but the conviction is on appeal. For additional cases involving negligent homicide, see text following note 148 infra. 
the abortion was performed by a licensed physician to terminate a pregnancy resulting from rape. ${ }^{101}$ The other example occurred a few years ago, during the public debate on reforming the abortion laws. About 370 women, some of them well known in German society, publicly announced in a leading magazine that they had in the past had an abortion. Prosecutors were arguably obliged to act; they maintained, however, that the announcements did not constitute sufficient evidence to begin prosecution. The police apparently did not investigate further. Thus far, none of the women seems to have been prosecuted.

Shoplifting is usually treated in the same manner as petty pilfering..$^{102}$ Deterrence and equal enforcement of the law are seen as requiring prosecution of all reported offenses. National chains of department stores usually report every offender; local stores, however, frequently favor private settlements. ${ }^{103}$ As a result, the rule of compulsory prosecution arguably leads to some inequity in enforcement of the law. Nevertheless, the rule is strictly followed.

Strict enforcement of the pure food and water laws, in particular more recently, has been considered necessary. But when an elderly woman cleaned her stove and illegally discharged a small amount of oil into the public sewage system, no charges were brought. The main reason for the failure to prosecute was that, in the same city, a chemical plant was discharging toxic waste waters into the same system. The plant could not be prosecuted, since it had been arguing with the water authorities for years and had been able to delay the final order of the water authority-a prerequisite to prosecution.

When violations of the old Narcotic Drugs Act became a serious problem in Germany, violators were prosecuted, almost without exception, as a means of deterrence. Today prosecution tactics have changed. The Narcotic Drugs Act of 1972 allows the judge to refrain from imposing punishment if the defendant possessed only a small amount of narcotics for his personal use. ${ }^{104}$ The Code of Criminal Procedure authorizes the prosecutor, with the court's consent, not to prosecute for the same reasons. ${ }^{105}$ These provisions are often utilized. In addition, when small amounts of drugs are given to a third person, or when the offender is willing to undergo treatment, prosecuting attorneys are

101 von Nottbeck, Die Straffunktionen des Staates und der Gesellschaft, in ProsLemE DER STRAFRECHTSREFORM 48, 60-61 (1963).

102 See text at note 85 supra.

103 The stores might ask the offender to contribute to the firm's health insurance fund or to help pay for its security system.

104 Narcotic Drugs Act [BETÄUbungsmitTELGesETz] \& $11(5)$.

105 Code of Criminal Procedure § 1539 . 
inclined not to prosecute. ${ }^{106}$ In response to the growing drug problem in Germany, a proposed reform of the Code of Criminal Procedure would grant further prosecutorial discretion in drug cases. The proposal would allow prosecutors not to prosecute a small dealer if he helped police to uncover a more dangerous large dealer. ${ }^{107}$

A prosecutor is occasionally tempted to consider the disastrous consequences a conviction will have on the life of the accused. The defendant might hold a business position he will lose, he may be a public official who will be exposed to disciplinary measures more serious than criminal punishment, or he may be required to forfeit a trade license or concession. Considerations of this nature should not affect the actions of the prosecuting attorney. ${ }^{108}$ The extent to which prosecutors do take the possible consequences of conviction into account cannot be determined, but these considerations probably affect some cases. ${ }^{109}$ The concepts of minor guilt and non-existent public interest are sufficiently flexible to cover most of these considerations, ${ }^{110}$ but the principles of compulsory prosecution and restrained discretion are the prevalent ones. Experienced defense attorneys maintain that prosecutors sometimes are more reluctant to close a case if a prominent citizen is involved or if they are afraid that the decision will be publicly criticized.

To drop a case the prosecutor must get the consent of the judge who would try it if a charge were brought. ${ }^{111}$ This requirement is intended to subject the prosecutor to judicial control and thus to guarantee that the rule of compulsory prosecution will not be undermined by a single attorney. The judge, however, routinely consents. ${ }^{112}$ Refusal to permit the case to be dropped occurs only in the rare cases in which the judge is aware of facts unknown to the prosecutor. Although prosecution offices are located only in cities, the courts are distributed all over the country. For crimes committed in rural areas, the judge in the local court might therefore be better informed about the case. In other cases, the judge might be able to inform the prosecutor that the case is part of a bigger criminal enterprise deserving punishment for deterrent

106 Juveniles are often involved in these cases. Prosecutorial discretion in cases involving juveniles is discussed at notes $164-70$ infra.

107 ENTwUrF eines ERsten Gesetzes zUR Reform des StrafverfahrensRechts of May 2, 1973, Deutscher Bundestag, 7. WAhlPERIOde, Drucksache VII/551, § 153 .

108 Kohlhaas, supra note 86, at 241.

109 See id. at 241.

110 See Heinitz, supra note 8, at 335; K. Homann, supra note 58, at 106.

111 Code of Criminal Procedure § 153(2). After the charge is brought, the judge may terminate proceedings with the prosecutor's consent. Id. $\$ 153(3)$.

112 If consent is withheld the prosecutor may raise a formal complaint-an action that is never taken. 
reasons. In general, however, the requirement of judicial consent is only an indirect restraint on the prosecutor's discretionary powers. As noted above, ${ }^{113}$ the major restraint on the individual prosecuting attorney's discretion exists within the local prosecution office. A prosecutor's decision not to prosecute because of minor guilt and non-existent public interest must be approved by a superior in the same way as a decision to close a case for lack of sufficient evidence. In addition, the victim, if he reported the offense, is notified. ${ }^{114}$ The victim can then object to the prosecutor's decision through a departmental complaint; the same procedure is available to the accused when the prosecutor insists on prosecuting. ${ }^{115}$

\section{G. Conditional Termination of Proceeding for Misdemeanors and Petty Misdemeanors}

Attorneys and prosecutors have pointed out that a defendant who can afford the assistance of counsel has a somewhat better chance of having his case closed. In a few cases involving misdemeanors or petty misdemeanors the defense lawyer stated to me that he had contacted the prosecutor and tried to dissuade him from bringing charges. Lawyers argue, for example, that the crime was not likely to be repeated, the accused was injured by the offense, or he has made full restitution to the victim. They may also indicate that the accused is willing to repent by paying a sum of money to a charitable institution. If the defense counsel is known by the prosecutor, his arguments will usually be considered. Occasionally a defense counsel might even attempt to exert some pressure on the prosecutor by stating that, if charges are brought, he will request that several additional witnesses be summoned for the trial. ${ }^{116}$ Such tactical maneuvers are, however, rarely used. Defense counsel must be careful not to damage the good relations he enjoys with the prosecutor.

Under the Uniform Rules of Criminal Procedure the prosecutor may consider the offender's conduct subsequent to the offense and ask whether the offender's guilt can in retrospect be deemed insignificant. ${ }^{117}$ While the defendant may not be exposed to any pressure, ${ }^{118}$ the prosecutor is authorized to inform the accused that acts such as payment of damages to the victim might affect the assessment of his guilt. On the other hand, the Uniform Rules explicitly forbid conditioning the

113 See text in the paragraph following note 49 supra.

114 Uniform Rule of Criminal Procedure 79(3).

115 See text at note 49 supra.

116 H. DAFs, supra note 39 , at 156 .

117 Uniform Rule of Criminal Procedure 83(3).

$118 \mathrm{Id}$. 
closing of a case on the accused paying the expenses of prosecution, or contributing to the public treasury or a charitable trust. ${ }^{119}$ During the Nazi period, prosecuting attorneys could close cases on these conditions, but after World War II they lost the right to do so..$^{120}$

Nevertheless, prosecutions for misdemeanors and petty misdemeanors are occasionally discontinued after the accused has made a stipulated payment to a charitable institution.121 Prosecutors do not expressly impose conditions and generally do not take the initiative. Defense attorneys, however, are aware of the possibility of working out a settlement; they usually take the first step by suggesting that their client would be willing to make a charitable donation if he could expect his case to be closed. In some instances, prosecutors felt free to suggest a higher sum if the offered contribution was too small. In a few cases, careful bargaining dragged on for weeks.

It is difficult to get reliable information about this practice, because settlement proceedings are informal and neither the prosecutor nor the accused wants any publicity. Settlements seem to be more frequent in larger cities than in other parts of the country. There are some prosecuting attorneys, however, who never engage in such bargaining. In a South German city, for example, settlements were almost entirely done away with when one of the top officials in the local prosecution office decided to reject them.

Defendants' donations to charitable institutions are usually a few hundred marks. To avoid prosecution, an automobile driver who was accused of speeding at 80 miles-per-hour in a 50 miles-per-hour zone paid one hundred marks to a church. ${ }^{122}$ When a public officer was prosecuted for seriously insulting a private individual, he offered to give five hundred marks to an institution that cares for crippled children. ${ }^{123} \mathrm{~A}$ cab driver accused of an illegal citizen's arrest donated

119 Id. 82(4).

$120 \mathrm{~J}$. KRüMPELMAN, supra note 81, at 205; Bartsch, Einstellung gegen BusszahlungUnzulässiger Freikauf von der Strafsanktion, 1969 ZeITschrifT FüR RECHTSPOLITIK 128, 129; General Instruction given by the Attorney General of Celle to the prosecuting attorneys of his district on May 2, 1946, 1946 HANNOVERSCHe REGFTSPFLEGE 57.

121 H. DAFS, supra note 39, at 156; J. KRüMpelManN, supra note 81, at 226; Bartsch, supra note 120, at 128-29; Becker, Bussgelder in Strafrecht, 1972 MoNATsschrift FüR DeUtsGHes ReckT 575, 576; H. Lange-Fuchs, letter to the editor, 1969 ZeItschrifT FüR REchTsPoLrTIK 216; Schmidhäuser, Freikaufuerfahren mit Strafcharakter im Strafprozess?, 1973 JURISTENZeITUNG 529, 532.

122 See decision of the District Court of Stuttgart, 1969 Monatsschrufr für DeUtsches RECHT 598. Most of the cases closed after the accused has made a charitable donation apparently involve traffic offenses.

123 Public prosecution in this case was said to be required by the public interest. See text at notes 52-57 supra. 
five hundred marks to the Red Cross. ${ }^{124} \mathrm{~A}$ wholesale food dealer who had violated provisions of the food law paid three hundred marks to get his case closed. A real estate agent prosecuted for irregular business activities paid one hundred marks. One defense attorney even signed a contract of suretyship regarding his client's proposed payment. ${ }^{125}$

Prosecutors ordinarily agree to a settlement only in trivial cases in which there is no doubt that the offender's guilt is minor. There have been a few misdemeanor cases, however, in which investigations were dropped after a voluntary donation by the accused even though serious offenses, mostly white collar crimes, were involved. In one case, a bankrupt accused of large scale frauds and violations of corporation laws had his prosecution averted after paying a considerable sum to the German section of the Red Cross. ${ }^{126}$ In another, a wholesale meat dealer was charged with evading taxes and customs duties totalling 1.4 million marks; a Hamburg prosecutor ended the proceedings after the accused donated four hundred thousand marks to various charitable institutions. ${ }^{127}$ This incident became a public scandal after it was revealed that one hundred thousand marks were paid to an association of which the prosecutor was president. The prosecutor, and the judge who had given the required consent even though he had no jurisdiction, were collecting sizable honorariums from the association for public speeches. Both were suspended from office, and the prosecutor later committed suicide. A commission of inquiry set up by the Hamburg parliament discovered that closing serious cases in return for large charitable contributions had been practiced in the city of Hamburg for some time. ${ }^{128}$ The practice was, of course, condemned.

A case that received even more public attention was the termination of proceedings against the manufacturer of Thalidomide, a sleeping pill that caused thousands of embryonic deformations and hundreds of nervous disorders. ${ }^{129}$ The proceedings were discontinued by the court,

124 This example, and the two that follow, are cited by Bartsch, supra note 120, at $128-29$.

125 Decision of the District Court of Cologne, 1962 NeUE JuRIstische Wochenschruft 1024. In this case proceedings were discontinued not by the prosecutor, but by the judge with the prosecutor's consent.

126 See K. Tiedemann, letter to the editor of Frankfurter Allgemeine Zeitung [a leading German newspaper], May 7, 1969, at 10.

127 See Schmidhäuser, supra note 121, at 529; DER SPIEGEd [a leading German political magazine], May 23, 1972, at 67; Frankfurter Allgemeine Zeitung, Jan. 12, 1972, at 3. The prosecutor was the head of the section dealing with white collar crimes and did not need anyone's approval for the settlement.

128 Schmidhäuser, supra note 121, at 529.

129 Decision of the District Court of Aachen, 1971 JuRISTEnzertung 507; Bruns. Ungeklärte verfahrensrechtliche Fragen des Contergan-Prozesses, in FESTSCHRIFT Für 
rather than the prosecutor, after a trial of over two-and-a-half years. ${ }^{130}$ The court held that the guilt of the defendants, managers and chemical engineers for the firm, was minor after being exposed to a long, highly publicized trial and after the firm had offered to pay one hundred and fourteen million marks into public trusts for the victims. ${ }^{131}$ The public interest in a judicial resolution of the case was considered subordinate to the victims' interests in a financial settlement. ${ }^{132}$ This case, for a number of reasons, must be called exceptional. But it indicates that the standards of minor guilt and public interest are susceptible to flexible interpretation. The practice of restrained discretion is obviously not derived from the language of the Code of Criminal Procedure, but rather from a consensus of the prosecutors who act according to the rule of compulsory prosecution.

A considerable number of commentators maintain that settling cases as a result of a voluntary donation by the defendant is illegal. ${ }^{133}$ They argue that a payment cannot be deemed voluntary when the defendant's alternative is prosecution. ${ }^{134}$ The practice has also been criticized for allowing wealthy offenders, in particular white collar criminals, to buy their way out of criminal proceedings. ${ }^{135} \mathrm{It}$ is further argued that pecuniary obligations should be imposed only by the trial judge, who assesses the defendant's guilt in a public trial after hearing the evidence. ${ }^{130}$ Nevertheless, settlement proceedings are neither expressly

ReInhart MaUrach 469 (1972); Dahs, Ein Monstrum verschwindet im Nichts, Die Zeit [a German weekly paper], Jan. 1, 1971, at 36 .

130 A court may close a case on the same conditions as a prosecutor.

131 Decision of the District Court of Aachen, 1971 JuRistenzerrung 507, at 519-20. See also Stellungnahme der Staatsanwaltschaft im Contergan-Prozess [reasons given by the prosecutor for his consent to close the case], 1971 Deutsche Richterzertung 45, 48-49.

132 Id.

133 J. KRÜMPeimanN, supra note 81, at 228; E. SchMid, LeHrKommentar zUR STrafprozessordnung, NAchtragsband I, § 153, annot. No. 9 (1966); Bartsch, supra note 120, at 128-30; Dencker, Die Bagatelldelikte im Entwurf eines EGStGB, 1973 JURISTENZEITUNG 144, 149; Hanack, Das Legalitätsprinzip und die Strafrechtsreform, in FESTSCHRIFT FüR WLHELM GaLLAS 339, 344 (1973); Kern, Wer trägt die Kostern bei Einstellung des Strafuerfahrens wegen Geringfügigkeit (gemäss § 153 Abs. 3 StPO)?, 1953 DeUtsche Richterzertung 169; Schmidhäuser, supra note 121, at 532; Trapp, Kann die Einstellung nach $\$ 153$ Abs. 1 StPO von der Zahlung einer Geldbusse abhängig gemacht werden?, 1958 NeUE JURIsTische WOCHENSCHRIFT 292.

134 Bartsch, supra note 120, at 130; Dencker, supra note 133, at 149; Schmidhäuser, supra note 121 , at 534 .

135 Decision of the District Court of Cologne, 1962 NeUE JURISTISche Wochenschrift 1024; Bartsch, supra note 120, at 130; Cordier, Kann die Zahlung einer Geldbusse zur Voraussetzung einer Einstellung nach § 153 Abs. 1 StPO genacht werden?, 1957 NEUE JURISTISCHE WOCHENSCHRIFT 1789, 1791; General Instruction by the Attorney General of Ceile, supra note 120.

136 J. KRÜMpelManN, supra note 81, at 228; Cordier, supra note 135, at 1790; Jescheck, supra note 2, at 514; Trapp, supra note 133, at 293. 
forbidden nor expressly allowed by the Code of Criminal Procedure and the Uniform Rules, and they are sanctioned by some courts and a number of legal writers. ${ }^{137}$

Recent efforts to increase the speed of the criminal process and to cope with the rapidly growing caseload of the prosecutors have resulted in a proposed reform of the Code of Criminal Procedure that would expand the scope of prosecutorial discretion. ${ }^{138}$ The proposal authorizes the prosecutor in misdemeanor cases to decide not to prosecute on the condition that the accused makes restitution, contributes a sum of money to the public treasury or a charitable trust, guarantees support for a dependant of the victim, or performs some other act in the public interest. ${ }^{139}$ If the accused complies with the condition within a period set by the prosecutor, the case is finally closed; otherwise, the prosecution is reopened.

This proposal has been severely criticized by commentators who argue that it would introduce uncertainty into the German criminal process. ${ }^{140} \mathrm{It}$ is further argued that the sanctioned bargaining procedure would result in class injustice, favoring the white collar criminal who has sufficient means to pay. ${ }^{141}$ Finally, the procedure may be inconsistent with the presumption of innocence, since the accused would be pressured to cooperate. ${ }^{142}$ Despite these criticisms, the reform is likely to be approved by the legislature.

\section{H. Prosecutorial Discretion and the Judge's Power to Refrain from Imposing Punishment}

Under the Code of Criminal Procedure, the prosecutor may decide not to prosecute if he believes that the trial judge would be authorized to refrain from imposing a penalty even though the defendant is guilty. ${ }^{143}$ Several provisions of the Penal Code and other statutes give

137 Decision of the District Court of Stuttgart, 1969 Monarsschrifr Für DeUtsches REcht 598; decision of the District Court of Cologne, 1962 NeUE JuRISTISCHE WocheNSCHRIFr 1024; H. DAHs, supra note 39 , at 156-57; T. KLEINKNECHT, supra note 57, § 153, annot. No. 2(A); 1 Löwe-RosenberG, supra note 84, § 153, annot. No. 17; H. MüLLER \&: W. SAx, supra note 64, § 153, annot. No. 2(c); K. PETERs, supra note 5, at 149; Becker, supra note 121, at 576; Cordier, supra note 135, at 1791 .

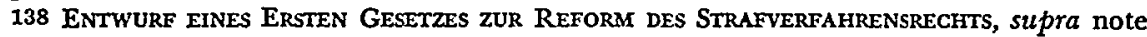
107 , § 153a.

139 The prosecutor would need the consent of both the judge and the accused.

140 Dencker, supra note 133, at 149; Hanack, supra note 133, at 347; Schmidhäuser, supra note 121 , at $533-36$.

141 Hanack, supra note 133, at 349-50, 358, 363; Schmidhäuser, supra note 121, at 535 .

142 Dencker, supra note 133, at 149-50; Schmidhäuser, supra note 121, at 534-35.

143 Code of Criminal Procedure § 153a; see Jescheck, supra note 2, at 514. The Uniform Rules of Criminal Procedure give no specific guidance for these cases. See Rule 84. 
the judge this power. ${ }^{144}$ By far the most important of these applies to cases in which the consequences of the offense to the offender were of such a serious nature that a penalty is clearly pointless. ${ }^{145}$ This provision is limited to cases that would not result in imprisonment of more than one year; prison sentences in Germany are, however, considerably less severe than in the United States, and even cases involving felonies may be covered. ${ }^{146}$

The provision was added to the Penal Code in 1969. ${ }^{147}$ Judges are still somewhat reluctant to use it and they have not yet reached a consensus on the cases to which it should apply. The same is true with respect to the exercise of the prosecutor's discretionary power not to prosecute such cases. As far as could be ascertained, prosecutions for felonies have never been terminated by prosecutors under this provision. For other offenses, the standard of self-inflicted harm has been liberally construed by courts and prosecutors. It includes bodily injuries and financial loss; damaging consequences to a relative of the offender or a person close to him can also be considered. ${ }^{148}$ The reason for not imposing punishment in these cases is not the triviality of the offense, but the notion that cases of this kind do not deserve punishment.

This motivation is clear from the following misdemeanor cases in which prosecutors declined to bring charges. A mother dropped her baby boy, but did not take him to a doctor. When the baby died a few days later, it was discovered that he had a fractured skull; the injury would probably not have been fatal if it had been treated in a hospital. The mother was not prosecuted. Motorists who negligently caused accidents that resulted in serious injuries to themselves and others were

144 One provision, dealing with possession of a small amount of drugs for the offender's personal use, was discussed at note 104 supra. In addition, the judge may refrain from imposing a penalty for false unsworn testimony by a person less than sixteen years old. His discretionary power also applies if the offender committed perjury to avoid subjecting himself or a member of his family to punishment. Penal Code $\$ 157$; Code of Criminal Procedure § 60. See also Penal Code § 129.

145 Penal Code $\$ 16$.

146 Although imprisonment of one year is the mandatory minimum for felonies, shorter sentences can be imposed if mitigating circumstances are found. For example, a provision on mitigating circumstances is included in the provisions for perjury, infanticide, robbery, and extortionary robbery.

147 Before the provision was enacted, judges tried to accomplish the same end in some cases by imposing nominal sentences. Prosecutors sometimes closed a case arguing that the accused had suffered by his own offense and thus his guilt was minor and punishment was not required by the public interest.

148 Decision of the High State Court of Appeals of Celle, 1971 Neve JuRistische WOCHENSCHRIFT 575; decision of the High State Court of Appeals of Frankfurt, 1971 NEUE JURISTISChe Wochenschrift 767; H. JEscheck, supra note 30, at 637; A. SchöNKE \& $\mathrm{H}$. SCHRÖDER, supra note $13, \S 16$, annot. Nos. 3,4 . 
sometimes not prosecuted. The same principle applied to a driver who did not harm himself, but caused injuries to a close friend and was deeply shocked by what he had done. The prosecutor's decision may be different, however, if the offender has acted recklessly or has previously caused other accidents.

Even reckless conduct resulting in serious harm does not always force the prosecutor to prosecute. When a farmer's wife carelessly left a box of matches on the kitchen table and her children got it and set the farm on fire, everyone in the prosecutor's office agreed that she had been sufficiently punished. ${ }^{149}$ The same result was reached when the owner of a store lost his shop and all of his inventory in a fire caused by his failure to turn off an electric heater.

Some prosecuting attorneys are willing to attach importance also to psychic and emotional consequences the offender suffered from his crime. The majority, however, feel bound by the rule of compulsory prosecution and the idea of restrained discretion, and are willing to consider only serious physical consequences to the offender.

\section{Prosecutorial Discretion and Multiple Offenses}

If several crimes have been committed by the same person, the prosecutor is not always required to prosecute each offense. In this regard it must be noted that in Germany, the entire criminal transaction is presented to the court, rather than merely those elements selected by the prosecutor. For example, if employees of a bank were taken as hostages and a police officer killed in the course of a bank robbery, the prosecutor presents all of the facts to the court and files a charge for all possible offenses; he cannot choose to prosecute only one of the offenses and thereby bring a reduced charge. ${ }^{150}$ A final judgment of conviction or acquittal is res judicata as to the entire transaction described in the charge.

The concept of the criminal transaction is not limited to acts committed in one place at one time. A transaction may include several

140 Negligently causing a fire is a misdemeanor in German criminal law.

150 Hence it would be useless for a defense attorney to try to bargain for such a reduction of the charge. The prosecutor in a case of this nature has no legal power to comply with the request to reduce a charge. Contrary to a statement by Professor Davis, K. Davis, supra note 1 , at 195 , this question is not one of prosecutorial discretion, because the prosecutor is legally prohibited from so doing. If a prosecutor illegally brought a reduced charge, it would not help the defendant; at trial, the evidence is presented by the judge, not by the prosecutor and defense counsel. The judge's actions are governed by section 155 of the Code of Criminal Procedure, which expressly provides that the judge is not bound by the legal counts of the prosecutor's charge. For details of the judge's activities at the German trial, see FoREIGN OFFICE, supra note 2, at 148-51; Jescheck, Germany, in J. Coutrs, The ACcused-A Comparative Study, 246 (1966); Schmidt, supra note 2, at 13-17; Wolf, Criminal Justice in Germany (pt. 2), 43 Mich. L. Rev. 155, 162-68 (1944). 
separable acts that can be considered one episode. A series of frauds committed in several cities by a travelling salesman, the writing of numerous bad checks, or the filing of several false tax returns have all been treated as one transaction. The causing of thousands of embryonic deformations and hundreds of nervous disorders by the manufacturer of Thalidomide was also held to be one criminal transaction consisting of numerous separate acts. ${ }^{151}$

In cases of this kind, a strict rule requiring careful investigation of each act would be an unreasonable burden on the prosecutor. $\mathrm{He}$ is therefore given discretion to prosecute only the most serious of the offenses, or to select typical samples out of a series of acts if the selected instances provide a sufficient basis for imposing adequate punishment. ${ }^{152}$

The Uniform Rules of Criminal Procedure encourage the prosecutor to exercise this discretionary power, particularly in voluminous or complex cases, to simplify and speed criminal proceedings. ${ }^{153}$ Prosecuting attorneys usually follow this advice without hesitation. The idea of restrained discretion is not taken as seriously here as in other cases. A leading commentator has suggested that charges may be dropped even if their prosecution would be likely to increase the punishment by onefourth. ${ }^{154}$

This discretion is often exercised, for example, in cases involving white collar crimes. Investigation of these crimes is usually extraordinarily difficult because many carefully concealed transactions must be uncovered, numerous victims and witnesses must be gathered, and voluminous files and papers must be searched. In big cases the defense attorney might contact the prosecutor to dissuade him from prosecuting some of the offenses. Careful bargaining between the defense counsel and prosecutor might follow.

Defense lawyers have told me that, in a few cases involving resisting arrest in addition to other offenses, prosecuting attorneys appeared to be quite willing not to prosecute that offense. The defendant claimed that the arresting officer used more force than necessary to make the arrest. The prosecutor was uncertain whether it would be harmful to the police officer to have the details of the arrest discussed in open court. He excluded the offense from the charge because he felt obligated to protect the police officer from adverse publicity.

151 Bruns, supra note 129 , at 473.

152 Code of Criminal Procedure §§ 154, 154a.

153 Uniform Rule of Criminal Procedure 86.

154 T. KLEINKNECHT, supra note 57, § 154a, annot. No. 2. 


\section{J. Prosecutorial Discretion Regarding Political Crimes and Crimes Committed Outside Germany}

Under continental European legal doctrine, German courts have jurisdiction over offenses committed by German citizens outside its territory. ${ }^{155}$ Offenses committed by foreigners are also within German jurisdiction if directed against the German state or one of its citizens, or if they involve, for example, illegal distribution of narcotics, trafficking in women and children, or counterfeiting. ${ }^{158}$ For various reasons, prosecution of these crimes might not be required by the public interest, even where a serious felony is involved. The offense may already have been punished in a foreign country, prosecution in Germany might cause undue hardship to the offender, or prosecution of a political crime might seriously jeopardize foreign relations.

The prosecutor has broad discretionary power over offenses committed outside Germany and political crimes. ${ }^{157}$ His actions are generally governed by considerations of expediency rather than the rule of compulsory prosecution. To decline to prosecute an offense committed outside Germany, the prosecutor must report the case to the attorney general of the state and leave the decision to him.158 The attorney general is in close contact with the ministry of justice and sees that foreign relations issues and difficult political problems are taken into consideration. Because the questions involved are primarily political, the judge's consent is not required to terminate such a case. In practice, the prosecutor's discretion in these cases is of minor importance because few cases of this type come to his attention.

Prosecution of the most serious political offenses is the responsibility of the Federal Attorney General. In 1968 the Code of Criminal Procedure was amended to authorize him not to prosecute even the most serious political crimes, such as high treason or espionage, if he believes that prosecution would be politically disadvantageous to Germany or that important public interests would present an obstacle to prosecution. ${ }^{160}$ In cases of espionage, for example, a prosecution could require disclosure of state secrets, thereby seriously endangering national

155 Penal Code $\S 3$.

$156 I d . \S 4$.

157 Code of Criminal Procedure §§ 153b, 153c; Uniform Rules of Criminal Procedure $84 \mathrm{~b}-84 \mathrm{f}$.

158 Uniform Rule of Criminal Procedure 84b.

150 Code of Criminal Procedure \$ 153c. See also Uniform Rules of Criminal Procedure 84e, 84f; Schram, supra note 2, at 627-31. Genocide and preparation for aggressive war, however, must always be prosecuted. 
security; or an agent for a foreign intelligence system might be willing to work for a German service in exchange for not being brought to trial.

Prior to 1968, prosecutors were required to bring charges for all serious political offenses. In fact, however, the rule of compulsory prosecution was never strictly followed in such cases. During the 1950s and 1960s East European countries, particularly East Germany, engaged in numerous surreptitious political activities directed against West Germany. West German authorities defended with the usual means of intelligence and counterintelligence, and a great number of political offenses were uncovered; many violations were not prosecuted. ${ }^{160}$ The Federal Attorney General at that time stated that it would be extraordinarily difficult to follow the rule of compulsory prosecution in political matters. ${ }^{161}$ There was no public dissent from this view.

Under the Code of Criminal Procedure, the Federal Attorney General is further authorized to decline to prosecute serious political crimes if the offender has helped to avert an imminent danger to Germany by dissuading other offenders or by disclosing the offense to German authorities. ${ }^{162}$ The offender's action in these cases is regarded as an act of repentance and considered a sufficient reason for exemption from punishment. ${ }^{103}$

\section{K. Prosecutorial Discretion in Proceedings Against \\ Juveniles and Adolescents}

The prosecutor exercises broad discretionary power in proceedings against juveniles, that is persons between 14 and 18 years of age. ${ }^{164}$ The Juvenile Court Act suggests that the prosecutors and judges who handle cases involving juveniles should be qualified and experienced as educators. ${ }^{165}$ Under the Juvenile Court Act, the prosecutor has complete discretion not to prosecute. ${ }^{166}$ Even felony cases may be terminated without a public charge. The juvenile's education is the predominant consideration in juvenile cases, so individualized justice is preferred to compulsory prosecution. Punishment is inflicted only if educational measures are insufficient.

Juvenile cases may be dropped in the same instances as prosecutions

160 See Schram, supra note 2, at 630.

161 M. GüDE, supra note 18, at 23. See also Schram, supra note 2, at 631.

162 Code of Criminal Procedure § 153d; Uniform Rule of Criminal Procedure 85.

$163 \mathrm{~K}$. Peters, Der Strafrrozess in Der Fortentwicklung 6 (1970); Jescheck, supra note 2 , at $511-13$.

164 See ForeIGN OFFICE, supra note 2, at 155; Jescheck, supra note 2, at 513.

165 Juvenile Court Act [JUGENDGERTCHTSGESETZ] \& 37.

186 Id. § 45. See also Jescheck, supra note 2, at 513. 
involving adults and also in the following additional circumstances. When the prosecutor believes that a trial is not required, he may, instead of bringing a charge, ask the judge to issue directives to the accused. ${ }^{167}$ The directives suggested by the prosecutor often include an order to work for a charitable organization. In a south German city, for example, young boys and girls guilty of shoplifting were usually required to work in an orphanage for fifteen to thirty hours in the evenings or during weekends. Juveniles may also be directed to make restitution for damage caused by their offense, to apologize to the victim, or to donate money to a charitable fund, preferably a fund that deals with juvenile problems. The use of donations is limited to exceptional cases to avoid creating an impression for young people that anything can be done with money. Restitution of damages, however, is often directed, because it confronts the juvenile with the effect of his offense. Thus, when young boys had broken public park benches, they were directed to build replacements; the judge further ordered that they do the building in the neighborhood youth center, where they would be in an environment beneficial to their rehabilitation. If juveniles violate traffic rules, they are generally sent to a traffic school conducted by police officers. The judge might also call the juvenile into his chambers and give him a stiff admonishment, but this action is generally regarded as ineffective. The directive procedure seems to work efficiently; it is frequently used and juveniles usually follow the judge's orders. Prosecutors suggest that directives be issued only if the accused has admitted his guilt. Otherwise they bring the case to trial.

The prosecutor does not always need the cooperation of a judge to close a case involving a juvenile. Educational steps may have already been taken by the defendant's parents or guardian, or by a school or other institution. ${ }^{168}$ The prosecutor may even suggest an appropriate educational measure. In some cases there are informal negotiations among the prosecutor and the concerned parties. When the prosecutor is satisfied that the accused's parents or the other persons have assumed responsibility so that there is no benefit from having a judge impose additional measures, proceedings may be terminated.

In addition, if the juvenile's guilt is minor, and prosecution is not required by the public interest, the prosecutor may drop a case without the consent of the judge and without any directives to the accused. ${ }^{160}$ Except in big cities, where prosecution offices are overburdened,

107 Juvenile Court Act $\S 45(1)$.

168 Id. § 45(2)1.

160 Id. $\S 45(2) 2$. 
prosecutors invoke this power only in rare instances. For policy reasons, they prefer to have a directive issued by a judge or another educational measure before closing a case.

Cases involving adolescents, persons between 18 and 21 years of age, are generally handled by prosecutors and judges qualified for juvenile matters. Such cases, however, may be closed only when a similar case against an adult could be closed. Thus prosecutors are not authorized to have directives issued or to impose conditions as in cases involving juveniles. In practice, however, prosecutors sometimes impose conditions or ask for directives. For offenses that are categorized as petty misdemeanors and offenses that are among the less serious misdemeanors, the prosecutor may suggest, for example, that an adolescent work for a charitable institution or make restitution for the damage. In effect the prosecutor will be willing to find the adolescent's guilt minor and prosecution not required by the public interest only if his request is obeyed. The legality of this tactic is highly disputed. ${ }^{170}$ Nevertheless, prosecutors resort to this practice, primarily because they tend to regard adolescents in a class with juveniles and thus try to exert an educational influence on them. Pedagogic motivations override the idea of restrained discretion. Judges do not hesitate to give the consent required in these cases.

\section{Further Instances of Prosecutorial Discretion}

The Code of Criminal Procedure also grants the prosecutor discretion not to prosecute in some other cases. First, the prosecutor may drop a case against an accused who is extradited to a foreign jurisdiction or expelled from Germany. ${ }^{171}$ There is usually no reason to bring charges against a person who leaves the country under such circumstances.

Second, if extortion is committed by threatening to reveal a previous offense by the victim and the victim reports the threats to the authorities, the prosecutor may decline to prosecute the victim for the prior offense unless the seriousness of the offense makes punishment necessary. ${ }^{172}$ This provision was primarily intended to prevent extortion among homosexuals. It never played an important role, however, partly because the public is unaware of it and partly because prosecutors strictly follow the rule of compulsory prosecution. ${ }^{173}$ The concept of restrained discretion is given effect in this area by the Uniform Rules

170 Cf. text and notes at 133-37, supra.

171 Code of Criminal Procedure $\$ 154 \mathrm{~b}$.

$172 I d$. $\$ 154 \mathrm{c}$. The decision might involve delicate problems, so it should be made by the head of the local prosecution office. See Uniform Rule of Criminal Procedure 87(2).

173 Peters, supra note 8, at 150; 1 LöwE-ROSENBERG, supra note 84, § 154c, annot. No. 1. 
of Criminal Procedure, which provide that nonprosecution of the victim is appropriate only if his offense appears less serious than the extortion in the case. ${ }^{174}$ The language of the Code of Criminal Procedure provides no basis for such a severe limitation on this form of prosecutorial discretion.

The Code of Criminal Procedure also protects the prosecutor from being forced to decide questions of private or public law that should be left to a court or an administrative agency. ${ }^{175}$ For example, if the mother of an illegitimate child charges the alleged father with a breach of the duty to support, ${ }^{178}$ the prosecutor may require her to apply for a judicial declaration that the man is actually the father. The same principle applies when two fishermen have a dispute about fishing rights and one reports the other for poaching; the prosecutor may order that the fishing rights be determined by the competent administrative agency. If the question is not decided within a period fixed by the prosecutor, he may drop the case. Proceedings may be terminated in this manner only if the offense involved is not a felony; prosecution of felonies is considered too important to depend on the initiative of a private person to have a collateral question decided. The provision allowing the prosecutor to require a prior adjudication of collateral rights was added to the Code in the 1930s to relieve the prosecutor's caseload, but it is almost never used.

A further instance of prosecutorial discretion, more important than the cases discussed thus far, is not dealt within the Code of Criminal Procedure. If the accused is too ill to stand trial, ${ }^{177}$ or if relevant legislation or a pertinent appellate court decision is expected in the near future, the prosecuting attorney may provisionally close the case after the evidence necessary for trial has been collected. For instance, when the laws against adultery and homosexuality among consenting adults were repealed in 1969, no prosecutions for the offenses were brought in the last months prior to the change in the law. There is a substantial controversy about whether the prosecutor in these cases should simply fail to prosecute or should make a formal decision to close a case. ${ }^{178}$ The formal procedure for closing a case suggested by the Uniform

174 Uniform Rule of Criminal Procedure 87(1).

175 Code of Criminal Procedure § 154d.

176 See text and note at note 98 supra.

177 If the accused cannot stand trial because of insanity, the prosecutor moves for a protective order issued by the judge and committing the accused to an institution. The accused need not be present at this proceeding. See Code of Criminal Procedure $\$ \S 429 \mathrm{a}-$ $429 \mathrm{~d}$.

178 I LöWE-RosenbERG, supra note $84, \S 205$, annot. No. 1; Krause, Die vorläufige Einstellung von Strafsachen praeter legem, 1969 GOLTDAMMER's ARCHIV FÜR STRAFRECHT 97, 98. 
Rules of Criminal Procedure ${ }^{179}$ provides unambiguous proof of the prosecutor's decisions. ${ }^{180}$ The person who reported the offense should be informed of the prosecutor's action. On the other hand, an officially announced decision would not be necessary when the postponement is expected to be short.

Finally, the prosecutor exercises some discretion in summary proceedings. In cases involving misdemeanors and petty misdemeanors the prosecutor may, instead of taking a case to trial, apply to the judge for a penal order. ${ }^{181}$ The application must give the details of the case and request a specific punishment. ${ }^{182}$ The judge then decides whether to issue a penal order solely on the basis of the prosecutor's application and the file of the case. The defendant has the right to refuse the penal order and demand a trial. In this procedure the judge may not impose any punishment other than a fine or imprisonment not exceeding three months or revocation of a driver's license for not more than a year..$^{183}$ Further, he is not authorized to impose any penalty other than that requested by the prosecutor. If the judge is unwilling to act favorably on the prosecutor's application, he must set the case for trial.

The penal order is a fast and inexpensive procedure, so it is used in many cases, usually those that are easy to decide and, according to the prosecutor and the judge, do not require a public trial. ${ }^{184}$ The penal order is, to some extent, comparable to the guilty plea or a plea of nolo contendere in American procedure; it can be regarded as an offer by the judge to the defendant to accept the prosecutor's charge and admit his guilt. ${ }^{185}$ If the accused accepts the offer, the penal order is binding, like a final judgment; ${ }^{186}$ if he objects, the summary proceedings are abandoned, and the case is tried according to ordinary procedures. ${ }^{187}$

By applying for a penal order the prosecutor obviously expresses in-

179 Uniform Rule of Criminal Procedure 88.

180 Rrause, supra note 178 , at 99.

181 FOREIGN OFFICE, supra note 2, at 144; Jescheck, supra note 2, at 515-16; Langbein, supra note 3, at 455-58; Wolff, supra note 150 , at 173-74.

182 Code of Criminal Procedure $\$ 408$.

183 Id. $\$ 407$.

184 Jescheck, supra note 2, at 516, indicates that more than 70 percent of the cases not closed by the prosecutor are disposed of by penal order. In 1969 the courts of the state of Hesse issued penal orders in almost 50 percent of the cases. 2 Löwe-Rosenberc, Die STRAFPROZESSORDNUNG UND DAS GERIGHTSVERFASSUNGSGESETZ: GROSSKOMOMENTAR § 407, annot. No. 12 (22d ed. 1973). According to Blankenburg, supra note 39, at 182, penal orders were issued in about 75 percent of the cases in Bade-Württemberg in 1971.

185 See Jescheck, supra note 2, at 515-16; Langbein, supra note 3, at 456-58.

186 Code of Criminal Procedure \$ 410.

187 Id. § 411. 
terest in avoiding a full trial. This inclination is, in a few cases, taken by defense counsel as an invitation to negotiations regarding the punishment. Counsel with a client ready to admit guilt might approach the prosecutor and indicate that a penal order would be accepted if punishment did not exceed a certain limit. In these negotiations the parties obviously do not try to reach a final agreement, instead they limit themselves to intimating their general intentions and preferences. Experienced criminal lawyers believe that prosecutors are, to some extent, willing to cooperate, but it is impossible to determine how much an offer to accept a penal order affects the prosecutor in fixing a specific penalty.

In most cases, unlike American plea bargaining, there are no negotiations regarding the offenses included in the penal order. Elimination of some charges is usually prohibited by the single-transaction rule. ${ }^{188}$ If the defendant is accused of committing several separable criminal acts, defense counsel might suggest to the prosecutor that a penal order would be accepted if some of the offenses were excluded.

\section{CoNGLUSION}

In various places this article has noted the difficulties in properly structuring prosecutorial discretion and balancing discretion against the rule of compulsory prosecution. The Code of Criminal Procedure and the Uniform Rules of Criminal Procedure try to guide discretion with fairly broad terms, but at most they provide only general guidelines. Indeed, a commentator has urged enactment of more precise legal rules and thereby stricter limits on prosecutorial discretion. ${ }^{189}$ The wisdom of this suggestion is questionable. Because of the diversity of the problems involved, only the most detailed provisions could effectively channel the prosecutor's exercise of discretion. Such detailed provisions would probably combine with the concept of restrained discretion to reduce prosecutorial discretion to a nullity.

The present system of placing the power to control discretion within the local prosecution office seems to be far more efficient. When a prosecuting attorney decides not to prosecute, he must obtain approval of his superior and officially close the case. A file is opened for each case and recorded in a central register in the local office. Superiors are thus able to follow the activities of individual prosecutors in each case.

When a prosecutor closes a case, he gives written reasons for his ac-

180 G. Kaiser, Strategien und Prozesse strafrechtlicher Soztalkontrolle 86 (1972). 
tion. ${ }^{190}$ In the more difficult cases he communicates the reasons for the decision orally to his superiors. These reasons, whether oral or written, provide an effective means for supervisors to standardize and structure the exercise of discretion. At the same time, the requirement of providing reasons restricts the prosecutor's decision to close a case. If, for example, a case involves a theft from a department store, prosecution is required for deterrence and equal enforcement of the law; a proper reason for closing the case will be difficult to find. In less common cases, however, it may be easier to find an acceptable reason not to prosecute.

To complete the picture of the German prosecutor's activities, one more factor should be mentioned. The prosecutor in a sense is isolated from the facts. He must investigate all offenses brought to his attention, but the initial investigation is typically performed by the police authorities. The police are legally obligated to investigate all cases other than petty misdemeanors and petty infractions, but in fact this duty is not discharged. Police officers exercise broad and unknown discretionary powers. As long as no file is opened and no superior is present, the police officer's discretion cannot be controlled. A study of police activities found that the police often did not investigate cases in which a misdemeanor or even a felony was committed. ${ }^{101}$ Police officers freely exercise their power to label acts as criminal or not criminal, and they often downgrade traffic violations. Thus, most cases are screened and sifted before they reach the prosecutor.

Despite the rule of compulsory prosecution for prosecutors and a complementary requirement for police officers, some offenses are almost never prosecuted in Germany. Wildcat strikes, for example, are classified as misdemeanors under the Penal Code, yet no prosecution has followed various highly publicized wildcat strikes. There is illicit work in Germany on a large scale, but the statute against illicit work is never enforced. Running a brothel is a misdemeanor under German criminal law, but brothels thrive in numerous cities. Police officers and prosecutors are certainly aware of their existence, but proceedings are initiated only in extraordinary cases. ${ }^{102}$

The German system of criminal procedure, unlike the American system, tries to control prosecutorial activities with the rule of compul-

$190 \mathrm{~K}$. DAvis, supra note 1 , at 194, emphasizes that a written statement of reasons must always be given. Ordinarily prosecutors simply state that cases are closed because of insufficient evidence, minor guilt, or for some other equally uninformative reason. Blankenburg, supra note 89 , at 189.

$191 \mathrm{~J}$. FEest \& E. BLANKENBURG, supra note 84, at 58-113.

192 Heinitz, supra note 8 , at 385 . 
sory prosecution and the concept of restrained discretion. There are, however, some examples of discretionary power that are not expressly authorized by the Code of Criminal Procedure. It can be argued that the development of these exceptions indicates that the German system works effectively only because of this unofficial police and prosecutorial discretion. 